\title{
Characterizing NAD- and NADP-dependent Alcohol Dehydrogenase Enzymes of Strawberries
}

\author{
William C. Mitchell ${ }^{1}$ and Gojko Jelenkovic \\ Plant Science Department, Rutgers University, New Brunswick, NJ 08903 \\ Additional index words. Fragaria ×ananassa, fruit ripening, isozymes, organoleptic quality
}

\begin{abstract}
The NAD-dependent and NADP-dependent alcohol dehydrogenase activities of strawberries (Fragaria xananassa Duch.) were found to have broad substrate specificities including those alcohols and aldehydes responsible for strawberry aroma and flavor either directly or through their ester products. NAD-dependent activities were greatest against short-chained alcohols, whereas the NADP-dependent activities were most active against aromatic and terpene alcohols. Differences were seen in substrate specificity between receptacle and achene alcohol dehydrogenase activities. Alcohol dehydrogenase activities were found to be developmentally regulated in receptacle tissue and increased during the period of fruit maturation and ripening. Isoelectric focusing of NAD-dependent ADH activities showed that several isozymes of this enzyme exist, that they differ between receptacle and achene tissues, and that they vary among specific genotypes. Our results suggest that NAD- and NADP-dependent ADH activities are integral components of flavor and fragrance volatile production in ripening strawberries.
\end{abstract}

NAD-dependent (NAD-ADH; E.C. 1.1.1.1) and NADP-dependent alcohol dehydrogenases [NADP-ADH (cinnamyl alcohol dehydrogenase); E.C. 1.1.1.2] exist in a wide variety of higher plant tissues (Davies et al., 1973; Freeling and Bennett, 1985; Hatanaka et al., 1973; Kanellis et al., 1991; Noueiry, 1989; Roe et al., 1984; Tress1 and Albrecht, 1986; Yamashita et al., 1978). Putative roles attributed to plant alcohol dehydrogenases include surviving periods of hypoxia (Freeling and Bennett, 1985; Kanellis et al., 1991; Roe et al., 1984), regulation of development (Mitchell and Jelenkovic, 1992; Roe et al., 1984), production of cinnamyl alcohols for the lignification of cell walls (Davies et al., 1973), protection from chilling (C. Frenkel, personal communication), and biogenesis of flavor and fragrance volatiles (Hatanaka et al., 1973; Noueiry, 1989; Tress1 and Albrecht, 1986; Yamashita et al., 1978).

Biosynthetic pathways of alcohols, aldehydes, and esters implicated in flavor and fragrance production have been tentatively determined for many fruit (Tress1 and Albrecht, 1986). In strawberries, exogenously applied fatty acids, aldehydes and alcohols (Yamashita et al., 1977; Yamashita et al., 1979) were metabolized to their corresponding alcohols and esters. These results suggested that endogenous alcohols and aldehydes are interconverted by $\mathrm{ADH}$ in the pathway for producing the complex mix of volatile compounds (Honkanen and Hirvi, 1990) responsible for the characteristic flavor and fragrance of strawberries.

The present work examines the substrate specificity of strawberry ADH activities, the isozyme pattern of the NAD-dependent $\mathrm{ADH}$, and changes in $\mathrm{ADH}$ activities that occur during fruit ripening and development. Our results support the hypothesis that NAD-dependent and NADP-dependent ADH enzymes are important components of the in vivo biosynthetic pathway of strawberry flavor and fragrance volatiles.

Received for publication 18 July 1994. Accepted for publication 10 Apr. 1995. This research was supported by grant no. 12-113 from the New Jersey Agricultural Experiment Station. We thank Chaim Frenkel and Joseph Goffreda for their critical review of the manuscript. Use of trade names does not imply endorsement of the products named nor criticism of similar ones not named. The cost of publishing this paper was defrayed in part by the payment of page charges. Under postal regulations, this paper therefore must be hereby marked advertisement solely to indicate this fact.

'Present address: Biology Dept., Jersey City State College, Jersey City, NJ 07305.

\section{Materials and Methods}

Plant material. Primary fruit were freshly harvested from strawberry plants that were either grown in a greenhouse (genotype NJ 8343-6) or field (NJ 8336-1, NJ 8611-1, 'Earliglow', 'Raritan').

Four developmental stages of strawberries were used in this study. Stage 1 and stage 2 fruit had fully white receptacles and green achenes. Stage 3 fruit had receptacles with pink and white sections and green achenes. Stage 4 fruit were fully red, fragrant, and had brown achenes. Average fresh weights of stage 1 through stage 4 fruit were $0.315 \pm 0.056 \mathrm{~g}, 1.204 \pm 0.106 \mathrm{~g}, 6.492 \pm 1.236$ $\mathrm{g}$, and $8.302 \pm 2.015 \mathrm{~g}$, respectively.

Protein extraction from achenes. Protein extractions from achenes and receptacles were performed at $4 \mathrm{C}$. Achenes were removed from ripe strawberries, washed to remove debris, and air dried. Achene tissue was ground in $1.5-\mathrm{ml}$ microfuge tubes with tapered glass rods in an extraction buffer composed of $100 \mathrm{~mm}$ Tris- $\mathrm{HCl}, \mathrm{pH} 7.5,2 \% \mathrm{w} / \mathrm{v}$ soluble polyvinylpyrrolidone (PVP) as a phenolic scavenger, $1 \mathrm{~mm} \mathrm{ZnSO}$, $10 \mathrm{~mm} \beta$ - mercaptoethanol (BME) as a reducing agent, and the protease inhibitors $0.8 \mathrm{~mm}$ phenylmethylsulfonyl fluoride (PMSF), $1 \mathrm{~mm}$ benzamidine hydrochloride (BHC), and $5 \mathrm{~mm} \varepsilon-$ amino-n-caproic acid (ACA). 100 $\mu \mathrm{l}$ of buffer was used per $10 \mathrm{mg}$ of fresh weight. The extract was centrifuged for $15 \mathrm{~min}$ at $13,600 \times \mathrm{g}$ and the supernatant was collected as the enzyme source.

Protein extraction from receptacles. Strawberries were harvested and achenes were removed from the receptacles by peeling the epidermis away with razor blades. Achene-free receptacles were then homogenized in an extraction buffer composed of 100 mM Tris- $\mathrm{HCl}\left(\mathrm{pH} 8.5\right.$ ), $2 \%$ w/v PVP, $20 \mathrm{~mm} \mathrm{CaCl}_{2}, 0.1 \mathrm{~mm} \mathrm{ZnSO}_{4}$, $0.8 \mathrm{~mm}$ PMSF, $1 \mathrm{~mm} \mathrm{BHC}, 5 \mathrm{~mm}$ ACA, and $10 \mathrm{~mm} \mathrm{BME}$ in a food blender. The extract was filtered through one layer of Miracloth (Calbiochem) and the $\mathrm{pH}$ of the supernatant was adjusted to 7.5. The extract was then stirred for $15 \mathrm{~min}$ and centrifuged at $30,000 \times$ $\mathrm{g}$ to remove insoluble residues. The supernatant was made to $80 \%$ saturation in ammonium sulfate, stirred for $30 \mathrm{~min}$, and centrifuged $20,000 \times \mathrm{g}$ for $15 \mathrm{~min}$ to precipitate protein. The pellet was resuspended in a minimal volume of a buffer composed of $100 \mathrm{~mm}$ Tris- $\mathrm{HCl}$ (pH 7.5), $0.1 \mathrm{~mm} \mathrm{ZnSO}_{4}, 0.8 \mathrm{~mm}$ PMSF, $1 \mathrm{~mm} \mathrm{BHC,} 5 \mathrm{~mm}$ ACA, and $10 \mathrm{~mm}$ BME and dialyzed against $50 \mathrm{~mm}$ Tris- $\mathrm{Cl}(\mathrm{pH}$ 7.5), $0.1 \mathrm{~mm} \mathrm{ZnSO}_{4}, 0.8 \mathrm{~mm}$ PMSF, $1 \mathrm{~mm} \mathrm{BHC}, 5 \mathrm{~mm} \mathrm{ACA}$, and 10 mM BME. 
The protein extraction method for developmental studies was simpler. Achenes were removed from receptacles as above and the achene-free receptacles were homogenized in a Potter-Elvehjem tissue grinder, in an extraction buffer composed of $100 \mathrm{~mm}$ Tris$\mathrm{HCl}(\mathrm{pH} 8.5), 2 \%$ w/v PVP, $0.1 \mathrm{mM} \mathrm{ZnSO}_{4}, 0.8 \mathrm{~mm}$ PMSF, $1 \mathrm{~mm}$ $\mathrm{BHC}, 5 \mathrm{~mm} \mathrm{ACA}$, and $10 \mathrm{~mm}$ BME. The extract was adjusted to $\mathrm{pH}$ 7.5 and centrifuged at $13,600 \times \mathrm{g}$ for $15 \mathrm{~min}$ to pellet insoluble debris. The supernatant was used as the enzyme source.

ADH assays. All ADH assays were carried out at 24C. Oxidations of alcohols by $\mathrm{ADH}$ were assayed in reaction mixes containing $100 \mathrm{~mm}$ glycine- $\mathrm{KOH}(\mathrm{pH} 9.5)$ and $1.3 \mathrm{~mm}$ NAD or NADP, while reductions of aldehydes were assayed in reaction mixes containing $100 \mathrm{~mm}$ Tris- $\mathrm{HCl}(\mathrm{pH} 7.5)$ with $1.3 \mathrm{~mm} \mathrm{NADH}$ or NADPH. Substrate concentrations of $100 \mathrm{~mm}$ were used to developmental course assays. Substrate concentrations of $40 \mathrm{~mm}$ were used when comparing relative activities for different substrates (Tables 2 and 3), except for the substrates cinnamyl alcohol (20 $\mathrm{mM})$ and geraniol $(5 \mathrm{mM})$, which have relatively poor solubility in aqueous solutions. Calculation of $\mathrm{NAD}(\mathrm{P})$ formed was assessed by the change in $\mathrm{A}_{340}$ (Worthington, 1988). Preliminary results with strawberry NAD-dependent $\mathrm{ADH}$ gave a $\mathrm{K}_{\mathrm{M}}$ with ethanol as substrate of $6.96 \pm 0.32 \mathrm{~mm}$, and strawberry NADP-dependent ADH gave a $\mathrm{K}_{\mathrm{M}}$ with benzyl alcohol of $24.82 \pm 1.28 \mathrm{~mm}$. Our $\mathrm{K}_{\mathrm{M}}$ values were similar to those of other plant NAD- and NADPdependent ADH enzymes (Bicsak et al., 1982; Davies et al., 1973; Roe et al, 1984; Yamashita et al., 1978).

Native isoelectric focusing. Native isoelectric focusing (IEF) was performed on a horizontal flat bed Fisher Biotech FN 1001 IEF system according to manufacturers instructions. Gels $1 \mathrm{~mm}$ thick were composed of $1 \%(\mathrm{w} / \mathrm{v})$ agarose, $13 \%(\mathrm{w} / \mathrm{v})$ sorbitol, $6.7 \%(\mathrm{v} /$

Table 1. ADH activities of stage four strawberries. ${ }^{\mathrm{z}}$

\begin{tabular}{lcccr}
\hline \hline $\begin{array}{l}\text { Type of } \\
\text { ADH }\end{array}$ & \multicolumn{2}{c}{$\begin{array}{c}\text { Activity/fresh wt } \\
\left(\mu \mathrm{mol} \cdot \mathrm{min}^{-1} \cdot \mathrm{g}^{-1}\right)\end{array}$} & \multicolumn{2}{c}{$\begin{array}{c}\text { Activity/fruit } \\
\left(\mathrm{nmol} \cdot \mathrm{min}^{-1}\right)\end{array}$} \\
\cline { 2 - 5 } activity & Achenes & Receptacles & Achenes & Receptacles \\
\cline { 2 - 6 } NAD-ADH & 4970 & 75.8 & 467 & 680 \\
NADP-ADH & 1272 & 11.0 & 120 & 99
\end{tabular}

"Activities were determined for primary fruit of genotype NJ 8343-6. NAD-ADH activity was measured using 100 mm ethanol as substrate, and NADP-ADH activity was measured using $100 \mathrm{~mm}$ benzyl alcohol as substrate.

Table 2. Substrate specificity of strawberry NAD-ADH. ${ }^{2}$

\begin{tabular}{lcc}
\hline \hline & \multicolumn{2}{c}{$\begin{array}{c}\text { Specific activity } \\
\left(\mathrm{nmol}^{-1} \mathrm{~min}^{-1} \cdot \mathrm{mg}^{-1}\right)\end{array}$} \\
\cline { 2 - 3 } Substrate & Receptacles & Achenes \\
\hline Benzyl alcohol & $0.0 \pm 0.0$ & $14.9 \pm 8.6$ \\
1-Butanol & $295 \pm 27$ & $289 \pm 25$ \\
2 Butanol & $48.8 \pm 2.8$ & $53.4 \pm 5.7$ \\
Cinnamyl alcohol & $0.0 \pm 0.0$ & $9.9 \pm 5.7$ \\
Ethanol & $531 \pm 6$ & $621 \pm 66$ \\
Gcraniol & $196 \pm 33$ & $82.0 \pm 9.5$ \\
1-Hexanol & $46.8 \pm 5.4$ & $90.0 \pm 4.0$ \\
cis-3-Hexen-1-ol & $104 \pm 6$ & $169 \pm 4$ \\
Isuanyl alcohol & $123 \pm 29$ & $119 \pm 13$ \\
Methanol & $0.0 \pm 0.0$ & $8.1 \pm 4.7$
\end{tabular}

"Specific activity for NAD-ADH (genotype NJ 8336-l) was measured using $40 \mathrm{~mm}$ substrate except in the cases of cinnamyl alcohol and geraniol, where $20 \mathrm{~mm}$ and $5 \mathrm{~mm}$ were used, respectively. Values are \pm SE.

Table 3. Substrate specificity of strawberry NADP-ADH. ${ }^{z}$

\begin{tabular}{lcc}
\hline \hline & & $\begin{array}{c}\text { Specific activity } \\
\left(\mathrm{nmol} \cdot \mathrm{min}^{-1} \cdot \mathrm{mg}^{-1}\right)\end{array}$ \\
Substrate & \multicolumn{2}{c}{ Achenes } \\
\cline { 2 - 3 } Benzyl alcohol & Receptacles & $137 \pm 3$ \\
1-Butanol & $64.7 \pm 6.7$ & $32.0 \pm 1.3$ \\
2-Butanol & $17.6 \pm 0.3$ & $26.1 \pm 1.0$ \\
Cinnamyl alcohol & $0.0 \pm 0.0$ & $269 \pm 11$ \\
Ethanol & $105 \pm 3$ & $5.6 \pm 0.5$ \\
Geraniol & $0.9 \pm 0.3$ & $103 \pm 20$ \\
1-Hexanol & $88.3 \pm 3.5$ & $117 \pm 5$ \\
cis-3-Hexen-1-ol & $50.4 \pm 0.6$ & $84.6 \pm 3.8$ \\
Isoamyl alcohol & $29.0 \pm 0.3$ & $4.3 \pm 0.2$ \\
Methanol & $11.6 \pm 0.6$ & $0.0 \pm 0.0$
\end{tabular}

${ }^{2}$ Specific activity for NADP-ADH (genotype NJ 8336-1) was measured using 40 mM substrate except in the cases of cinnamyl alcohol and geraniol, where $20 \mathrm{mM}$ and $5 \mathrm{mM}$ were used, respectively. Values are \pm SE. 
v) ampholines ( $\mathrm{pH} 4$ to 6.5), and 1\% (v/v) Triton $\mathrm{X}-100$ (Fisher). The electrode buffers were $0.05 \mathrm{~N} \mathrm{H}_{2} \mathrm{SO}_{4}$ and $1 \mathrm{~N} \mathrm{NaOH}$. Electrophoresis was carried out with $15 \mathrm{~W}$ constant power for $2 \mathrm{~h}$ at $9 \mathrm{C}$. After electrophoresis, gels were stained for NAD-dependent ADH activity, with ethanol as substrate as by Noueiry (1989).

Staining IEF gels for NADP-ADH activity using benzyl alcohol as substrate was unsuccessful. Eggplant fruit and seed NADPdependent ADH enzymes were stainable with NADP cofactor and various substrates (including benzyl alcohol and coniferyl alcohol) after nondenaturing polyacrylamide gel electrophoresis (unpublished data). This leads us to believe that NADP-dependent $\mathrm{ADH}$ is unstable during IEF.

The pI measurements of histochemically localized $\mathrm{ADH}$ isozymes were determined by directly measuring the $\mathrm{pH}$ gradient in the gels (Garlin, 1990).

\section{Results and Discussion}

$\mathrm{ADH}$ activities in fruit. NAD- and NADP-dependent ADH activities of stage four strawberries are compared in Table 1. NADdependent ADH activity was 65.6-fold greater and NADP-dependent $\mathrm{ADH}$ was 116-fold greater for achene tissue than for receptacle tissue on a fresh-weight basis. The total NAD-dependent $\mathrm{ADH}$ activity of achenes on a stage 4 fruit was $31.3 \%$ less than the activity found in receptacles, while the total NADP-dependent ADH activity of achenes was $21.2 \%$ greater than the activity found in receptacles. NAD-dependent ADH activity was found to be 3.9and 6.9-fold greater than the NADP-dependent activities found in achene and receptacle tissues respectively.

The NAD-dependent ADH activity of receptacles (Table 2) was highest against ethanol and showed considerable activity against other unbranched primary alcohols. The receptacle enzyme also showed high activity against terpene (e.g., geraniol), branched (e.g. isoamyl alcohol), and unsaturated six-carbon (e.g., cis-3hexen-1-ol) alcohols.

Strawberry receptacle NADP-dependent ADH (Table 3) showed greatest activity against aromatic (e.g., cinnamyl alcohol and benzyl alcohol) and terpene alcohols and a lesser activity against four- and six-carbon primary alcohols. A weak correlation existed between the hydrophobicity of each substrate and the activity of the NADP-dependent enzyme for each substrate (e.g., the activity against aromatic alcohols and geraniol $>$ four and six carbon primary alcohols > ethanol).

The reduction of an aliphatic and an aromatic aldehyde by receptacle $\mathrm{ADH}$ was assessed. NAD-dependent $\mathrm{ADH}$ reduced acetaldehyde at twice the rate it reduced benzaldehyde, whereas, NADP-dependent ADH reduced benzaldehyde at nearly six times the rate of acetaldehyde.

The specificity of the NAD-dependent ADH of achenes (Table 2) was similar to that found in receptacles, except that the achene enzyme showed less relative activity for terpene alcohols and more relative activity for unsaturated six carbon alcohols and aromatic alcohols. Achene NADP-dependent ADH (Table 3) showed lesser affinity for branched alcohols and higher affinity for secondary straight-chained alcohols compared to receptacle NADP-dependent ADH.

Figure 1 shows a zymogram of strawberry achene and receptacle NAD-dependent ADH isozymes after separation by native IEF. Strawberry receptacles exhibited three to six isozymes depending on the genotype. Noueiry (1989) had previously documented the presence of strawberry achene NAD-dependent ADH isozymes. Differences in isozymes might confer differences in the substrate specificities of the enzymes from different sources.
Isozyme differences may account for the differences in substrate specificity we have seen between our achene NAD-dependent $\mathrm{ADH}$ and that of Yamashita et al. (1978) since the plants were genetically different.

Developmental control of ADH activity. The hypothesis that NAD-dependent and NADP-dependent ADH activities play important roles in flavor and fragrance production would be disproved if $\mathrm{ADH}$ activities did not increase before or during the time of fruit volatile production, that is, before or during the ripening process (stages 3 and 4). The ADH activities of entire strawberry receptacles were determined by enzyme assays for the four growth stages described in materials and methods. Total NAD-dependent ADH activity increased dramatically between stages 2 and 3 and afterward remained at relatively high levels (Fig. 2), whereas total NADP-dependent ADH activity increased gradually from stage 2 to stage 4 (Fig. 3). Specific activities of strawberry receptacle NAD- and NADP-dependent ADH (Figs. 2 and 3) showed their greatest increase between stages 3 and 4 . Our hypothesis about fruit $\mathrm{ADH}$ has therefore not been violated by the time course of $\mathrm{ADH}$ inductions during fruit growth and ripening. Our results agree with the observed developmental increases of NAD-dependent ADH in oranges and tomatoes (Chen and Chase, 1993; Roe et al, 1984) and increases of the NAD- and NADP-dependent ADH of eggplants (unpublished data).

Functions of fruit ADH. The well-documented role of NADdependent ADH's alleviating hypoxic stress through anaerobic respiration (Freeling et al., 1985) and the role of some NADPdependent ADH enzymes (cinnamyl alcohol .dehydrogenases), which synthesize cinnamyl alcohols and thereby allow lignification of woody tissues, seem to be inappropriate roles in strawberries. Strawberries have large surface to volume ratios, large intercellular air spaces and lack a thick cuticle (Darrow, 1966), characteristics that allow free gas exchange and reduce the likelihood of fruit hypoxia; their vasculature is unlikely to require significant lignification.

A putative role for strawberry NADP-dependent ADH in chilling protection can not be ruled out. Work on a possible stimulatory role for $\mathrm{ADH}$ in strawberry ripening (Mitchell and Jelenkovic, 1992) remains inconclusive.

Alcohols and aldehydes contribute to the characteristic flavor and fragrance of ripe fruit (Tress1 and Albrecht, 1986). The alcohols that contribute to the flavor of ripe strawberries (Honkanen
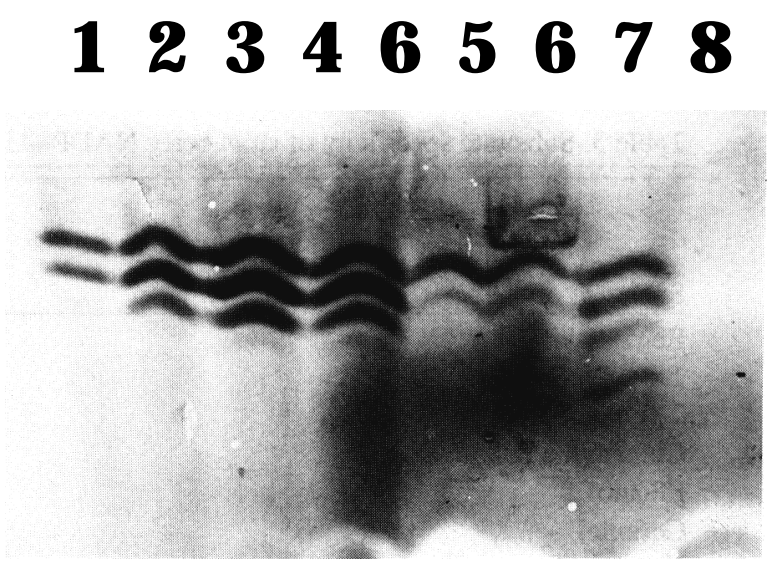

Fig. 1. Native IEF of stage four strawberry fruit NAD-ADH isozymes. Protein from $10 \mathrm{mg}$ of achenes or $250 \mathrm{mg}$ of receptacles were separated and histochemically developed on isoelectric focusing gels. The cathode is at the top of the figure. Lanes from left to right are 1) 'Raritan' achenes, 2) 'Earliglow' achenes, 3) NJ 8336-1 achenes, 4) NJ 861 I-1 achenes, 5) 'Raritan' receptacles, 6) 'Earliglow' receptacles, 7) NJ 8336-1 receptacles, 8) NJ 861 1-1 receptacles. 
Fig. 2. Developmental changes in NADdependent ADH activities in whole strawberry receptacles (genotype NJ 8336-1) over time. Assays used $100 \mathrm{~mm}$ ethanol as substrate as described under materials and methods. Bars represent the SE of the means.

and Hit-vi, 1990) were good substrates for one or both of the ADH activities characterized in this paper. In the future, we may be able to engineer strawberry flavor by selecting for specific fruit $\mathrm{ADH}$ isozymes. Genetic transformation of strawberry plants with a previously isolated gene for NADdependent $\mathrm{ADH}$ (Wolyn and Jelenkovic, 1990) could change the ADH present in the fruit and thereby allow direct analysis of the effect of an added ADH isozyme on fruit flavor and fragrance.

Our present work has indicated that 1) strawberry NAD- and NADP-dependent ADH could use the kinds of alcohols and aldehydes found in ripe strawberries as substrates (NAD-dependent $\mathrm{ADH}$ was more active against terpene and aromatic substrates), 2) receptacle NAD- and NADP-dependent ADH substrate specificities differed slightly, from those of the achene, suggesting a difference in $\mathrm{ADH}$ isozymes between tissues involved in flavor production (receptacle) and those not involved in flavor production (achenes); 3) NAD-dependent ADH was composed of polymorphic isozymes as shown by native IEF; 4) isozyme differences were seen between receptacle and achene tissues of the same genotype, showing additional ADH isozymes in the flavor production tissue (receptacle); and 5) the level of fruit ADH enzymes increased before and during ripening when they would be needed for flavor and fragrance volatile production. These results strengthen the hypothesis that NAD- and NADP-dependent ADH enzymes function as important components of the in vivo biosynthetic machinery of strawberry flavor and fragrance volatiles.

\section{Literature Cited}

Bicsak, T.A., L.R. Kann, A. Reiter, and T. Chase. 1982. Tomato alcohol dehydrogenase: Purification and substrate specificity. Arch. Biochem. Biophys. 216:605-615.

Chen, A.-R.S. and T. Chase. 1993. Alcohol dehydrogenase 2 and pyruvate decarboxylase induction in ripening and hypoxic tomato fruit. Plant Physiol. Biochem. 31:875-885.

Darrow. G.M. 1966. The Strawberry: history. breeding and physiology. Holt, Rinehart and Winston, New-York.

Davies, D.D., E.N. Ugochuku, K.D. Patil, and G.H.N. Towers. 1973. Aromatic alcohol dehydrogenase from potato tubers. Phytochemistry 12:531-536.

Freeling, M., and D.C. Bennett. 1985. Maize Adh 1. Annu. Rev. Genet. 19:297-323.

Garfin, D.E. 1990. Isoelectric focusing, p. 459477. In: M.P. Deutscher (ed.). Methods in enzymology. vol. 182. Guide to protein purification. Academic Press, Sari Diego.

Hatanaka, A., J. Sekiya, and T. Kajiwara. 1973. Distribution of an enzyme system

Fig. 3. Developmental changes in NADPdependent ADH activities in whole strawberry receptacles (genotype NJ 8336-1) over time. Assays used $100 \mathrm{~mm}$ benzyl alcohol as substrate as described under materials and methods. Bars represent the SE of the means.

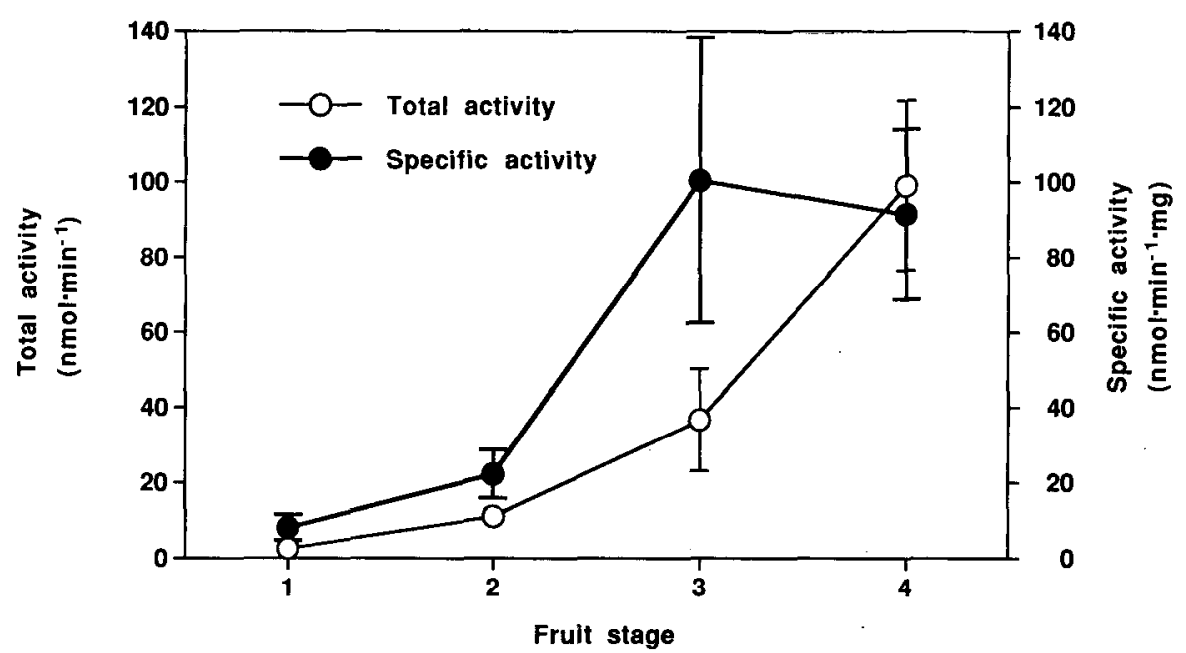

producing cis-3-hexenal and n-hexanol from linolenic and linoleic acids in some plants. Phytochemistry 17:869-872.

Honkanen, E. and Hirvi. 1990. The flavour of berries, p. 125-193. In: I.D. Morton and A.J. MacLeod (eds.). Food flavours. Part C. The flavour of Fruits. Elsevier, Amsterdam.

Kanellis, A.K., T. Solomos, and K.A. Roubelakis-Angelakis. 1991. Suppression of cellulose and polygalacturonase isozymes in avocado fruit mesocarp subjected to low oxygen stress. Plant Physiol. 96:269-274.

Mitchell, W.C. and G. Jelenkovic. 1992. NAD-dependent and NADPdependent alcohol dehydrogenase enzymes: Analysis of their functional significance in strawberry fruits. HortScience 27:594. (Abstr.)

Noueiry, A. 1989. Studies of differential activity and genetic nature of alcohol dehydrogenase isozymes in various plant parts of the octoploid strawberry, genotype 8343-6. MS thesis. Rutgers Univ.

Roe, B., P.L. Davis, and J.H. Bruemmer. 1984. Pyruvate metabolism during maturation of Hamlin oranges. Phytochemistry 23:713-717.

Tressl, R. and W. Albrecht. 1986. Biogenesis of aroma compounds through acyl pathways, p. 114-133. In: T.H. Parliment and R. Croteau (eds.). Biogeneration of aromas. Amer. Chem. Soc., Washington, D.C.

Wolyn, D.J. and G. Jelenkovic. 1990. Nucleotide sequence of an alcohol dehydrogenase gene in octoploid strawberry (Fragaria $\times$ ananassa Duch). Plant Mol. Biol. 14:855-857.

Worthington, C.C. 1988. Worthington enzyme manual. Worthington Biochemical Corp., Freehold, N.J.

Yamashita, I., K. Iino, Y. Nemoto, and S. Yoshikawa. 1977. Studies on flavor development in strawberries. 4. Biosynthesis of volatile alcohol and esters from aldehyde during ripening. J. Agr. Food Chem. 42: 1125-1 132.

Yamashita, I., K. Iino, and S. Yoshikawa. 1978. Alcohol dehydrogenase from strawberry seeds. Agr. Biol. Chem. 42:1125-1 132.

Yamashita, I., K. Iino, and S. Yoshikawa 1979. Substrate specificity in biosynthesis of volatile esters in strawberry fruit. Nip. Sho. Kog. Gak. 26:256-259. 